\title{
CLINICAL STUDIES ON THE RELATIONSHIP OF THE SHORT DURATION OF USE OF MIDAZOLAM WITH THE OCCURRENCE OF DELIRIUM IN ICU PATIENTS WITH MECHANICAL VENTILATION
}

\author{
ZHI-FENG CHEN \\ Department of Critical Care Medicine, Changde First People's Hospital 415000, Hunan Province, China \\ *corresponding author: zhifengchen@21cn.com
}

Manuscript received: March 2018

\begin{abstract}
The aim of the present study was to investigate the relationship between the short duration of use of midazolam and the incidence of delirium in ICU patients with mechanical ventilation. Patients in the ICU ward, who were continuously sedated and were under mechanical ventilation, were selected and enrolled into the study and divided into two groups: observation group, patients continuously sedated with midazolam; reference group, patients continuously sedated with propofol. Sufentanyl was used for analgesia for both groups. The information recorded from patients during sedation were as follows: adverse reactions (such as hypotension, bradycardia and nausea), onset time of sedatives, time to reach the optimal level of sedation, total duration of sedation, time to spontaneous eye opening, number of delirium cases, ICU length of stay, and occurrence of death within 28 days. The difference in the incidence of delirium and adverse reactions, ICU length of stay, and mortality in 28 days between the observation and reference groups was not statistically significant $(p>0.05)$. However, time to spontaneous eye opening was longer in the observation group $(\mathrm{p}<0.05)$. The onset effect time of sedatives was slightly longer in the observation group, compared with the reference group $(p<0.05)$. The difference in the time to reach the optimal level of sedation between these two groups was not statistically significant $(p>0.05)$. The incidence of delirium was similar between the observation and reference groups.
\end{abstract}

\section{Rezumat}

Scopul studiului a fost de a investiga relația dintre durata scurtă de utilizare a midazolamului și incidența delirului la pacienții cu tulburări psihice în unitatea de terapie intensivă (UTI). Pacienții, aflaţi sub sedare şi ventilație mecanică, au împărțiţi în două grupuri: grup de observație, pacienții sedați continuu cu midazolam și grupul de referință, pacienții tratați continuu cu propofol. Sufentanilul a fost utilizat pentru analgezie în cazul ambelor grupuri. Informațiile înregistrate în timpul sedării au fost următoarele: reacții adverse (hipotensiune arterială, bradicardie și greață), timpul până la atingerea nivelului optim de sedare, durata totală a sedării, timpul până la deschiderea spontană a ochiului, cazuri de delir, durata de spitalizare în UTI și rata mortalității în 28 de zile. Diferența dintre incidența delirului și reacțiile adverse, durata de spitalizare în UTI și mortalitatea în 28 de zile între grupurile de observație și de referință nu au fost semnificative statistic (p > 0,05). Cu toate acestea, timpul de deschidere spontană a ochiului a fost mai lung în grupul de observație $(p<0,05)$. Timpul de latență al sedativelor a fost ușor mai mare în grupul de observație, comparativ cu grupul de referință $(\mathrm{p}<0,05)$. Diferența în timpul de atingere a nivelului optim de sedare între aceste două grupuri nu a fost semnificativă statistic $(p>0,05)$. Incidența delirului a fost similară între grupurile de observație și cele de referință.

Keywords: midazolam, propofol, mechanical ventilation, sedation, delirium

\section{Introduction}

Delirium is a mental disorder with acute changes and fluctuation of mood, and is characterized by acute attack and reversibility. A number of epidemiological surveys have revealed that delirium is a common psychiatric disorder in the intensive care unit (ICU). A study has revealed that its incidence rate in the ICU has reached as high as $20 \%-80 \%$. The occurrence of delirium $[1,2]$ can lead to increased medical costs, longer hospital stay and higher mortality. It is presently known and proven by evidence [3] that sedatives may contribute to the occurrence of delirium. A study [4] has shown that the use of propofol does not significantly affect the incidence of delirium, while the use of midazolam resulted in an increased incidence of delirium in patients. However, it remains unknown whether the short duration continuous use of the latter would have less impact on delirium. In the present study, patients with mechanical ventilation requiring sedation and analgesia in the ICU were included as subjects, in order to investigate whether the short duration use of midazolam has less effect on the incidence of delirium.

\section{Materials and Methods}

\section{Subjects}

This study is a prospective, randomized, double blind controlled study. Patients in the ICU of Xiangya Hospital 
and Changde First People's Hospital, Hunan Province, China, from September 2013 to September 2014, who required continuous sedation with mechanical ventilation and met the inclusion criteria, were enrolled into the present study. Inclusion criteria: patients who were $\geq 18$ years old and $\leq 60$ years old, and patients with an expected sedation time $t$ of $\leq 72$ hours (classified according to the definition of short and long sedations in the Guideline for Analgesia and Sedation for Patients in the Intensive Care Unit, China). Exclusion criteria: patients who received cerebral surgery; patients with a history of central nervous system and mental illness (including Alzheimer's disease); patients with long-term use of antidepressants or sedatives, and alcoholics; patients with communication difficulties due to hearing impairment or visual impairment; patients with serious liver and kidney dysfunction, internal environment disorder, or hyperlipidaemia; patients in a coma; patients with obvious abnormal blood glucose and great fluctuations; patients with sepsis, unstable circulation, severe complicated hypoproteinaemia, anaemia and thrombocytopenia; patients allergic to midazolam or propofol. These patients were randomly divided into two groups. The specific method is to intercept 400 numbers on a random number table and allocate it to the observation group and the reference group according to the parity. The observation group continued using midazolam; the reference group continued using propofol sedation. A total of 120 patients (five patients who withdrew halfway were excluded) were included. Among these patients, 84 patients were male and 36 patients were female. Furthermore, among these patients, 30 patients had severe pneumonia, 19 patients had biliary tract infection, 12 patients had acute respiratory distress syndrome (ARDS), 2 patients had intestinal perforation, 8 patients had multiple injuries, 9 patients had urinary tract infection, 6 patients had myocardial infarction, 6 patients were poisoned, 4 patients had haemothorax, 10 patients had epidemic haemorrhagic fever, 13 patients had multiple burns on the body, 4 patients had pneumothorax, and 2 patients had abdominal infection.

Ethics approval and consent to participate

This study was conducted in accordance with the declaration of Helsinki. This study was conducted with approval from the Ethics Committee of Changde First People's Hospital. Written informed consent was obtained from all participants.

Drugs

Midazolam (Injection: 2mL: $10 \mathrm{mg}$ Liyuexi, Jiangsu Nhwa Pharmaceutical Co. Ltd.); propofol (Injection: $50 \mathrm{~mL}$ : $0.5 \mathrm{~g}$ Disoprofol, AstraZeneca).

Methods

Clinical and laboratory data were collected from all patients: age, gender, body weight, body temperature, pulse, blood pressure, respiration, blood oxygen saturation, arterial blood gas analysis, routine blood tests, routine urine tests, liver and kidney function and electrolytes, coagulation function, clinical diagnosis, and acute physiology and chronic health evaluation II (APACHE II) score within 24 hours of admission. Appropriate mechanical ventilation modes were selected according to disease treatment, blood gas analysis indicators were monitored, and respiratory parameters were adjusted. Patients in the observation group were treated with midazolam for sedation, and the loading rate was $0.05-0.1 \mathrm{mg} / \mathrm{kg}$ bw. After intravenous infusion, midazolam was routinely infused with a micro pump at a rate of $0.05-0.2 \mathrm{mg} / \mathrm{kg}$ bw/h for maintenance. The elderly and patients with liver and kidney dysfunction were given a reduced dose. Patients in the reference group were sedated with continuous infusion of propofol at a loading rate of $1-3 \mathrm{mg} / \mathrm{kg}$ bw. After intravenous infusion, propofol was routinely infused with a micro pump at a rate of $0.5-4 \mathrm{mg} / \mathrm{kg}$ bw/h for maintenance. A mental rating was performed every four hours, and the pumping dose was increased or decreased according to the Ricker sedation agitation score (SAS), in order to maintain the score within levels 3 - 4. Sufentanil was given for patients in both groups for analgesia at the same time, and the loading rate was $0.1-5.0 \mu \mathrm{g} / \mathrm{kg}$ bw. After intravenous infusion, sufentanil was routinely infused with a micro pump at a rate of $0.15-0.7 \mathrm{mg} / \mathrm{kg} \mathrm{bw} / \mathrm{h}$ for maintenance. According to the critical care pain observation tool (CPOT), the pain score remained at $0-3$. When the conditions improved, arterial blood gas analysis was performed. If indications for the withdrawal of ventilators were observed, sedatives were discontinued; and after the patient was conscious, the ventilator was removed and the endotracheal tube was pulled out. The patient's mental status was assessed daily before the patient was removed from the ICU after extubation, and delirium was assessed using CAM-ICU (the Confusion Assessment Method for the ICU) criteria. Observation indexes included the following: adverse reactions (e.g. hypotension, bradycardia, nausea, etc.) that occurred during sedation in each group, onset time of sedatives, time to reach the optimal level of sedation, the total duration of sedation, time to spontaneous eye opening, daily cost of sedation, number of patients with delirium, ICU length of stay, and the occurrence of death within 28 days.

\section{Statistics analysis}

All data in the present study were analysed using statistical software SPSS 18.0. Measurement data were expressed as mean \pm standard deviation (mean $\pm \mathrm{SD}$ ), and the comparison between the two groups was performed using two sample t-test. Count data were expressed as percentage, and were compared between the two groups using $\chi^{2}$-test. $\mathrm{P}<0.05$ was considered statistically significant. 
FARMACIA, 2020, Vol. 68, 1

\section{Results and Discussion}

\section{General information}

The differences in age, body weight, gender, disease profile and APACHE II score within 24 hours of admission to the ICU between the two groups were not statistically significant ( $\mathrm{p}>0.05$, Tables I and II).

Table I

Patients' gender, age and disease distribution of two groups

\begin{tabular}{llll}
\hline \multicolumn{1}{c}{ Item } & & Observation group $(\mathrm{n}=60)$ & Reference group $(\mathrm{n}=60)$ \\
\hline \multirow{2}{*}{ Age(years) } & $18 \leq \mathrm{y} \leq 40$ & 28 & 31 \\
\cline { 2 - 4 } & $41 \leq \mathrm{y} \leq 60$ & 32 & 29 \\
\hline Gender & Male & 44 & 40 \\
\cline { 2 - 4 } & Female & 16 & 20 \\
\hline Severe pneumonia & 16 & 14 \\
\hline ARDS & 6 & 6 \\
\hline Biliary tract infection & 10 & 4 \\
\hline Multiple trauma & 2 & 0 \\
\hline Intestinal perforation & 2 & 2 \\
\hline Abdominal infection & 0 & 0 \\
\hline Haemothorax & 4 & 4 \\
\hline Pneumothorax & 0 & 6 \\
\hline Epidemic haemorrhagic fever & 4 & 4 \\
\hline Poisoning & 2 & 2 \\
\hline Myocardial infarction & 4 & 6 \\
\hline Body multiple burns & 6 & 4 \\
\hline Urinary tract infection & 4 & 60 \\
\hline Total & 60 & \\
\hline
\end{tabular}

$\mathrm{AR} \overline{\mathrm{DS}}=$ acute respiratory distress syndrome

Table II

General information before treatment between observation group and reference group (Mean \pm SD)

\begin{tabular}{lcccc}
\hline \multicolumn{1}{c}{ Group } & $\begin{array}{c}\text { Age } \\
\text { (years) }\end{array}$ & $\begin{array}{c}\text { Body } \\
\text { weight }(\mathrm{kg})\end{array}$ & $\begin{array}{c}\text { Gender } \\
\text { (male/female) }\end{array}$ & $\begin{array}{c}\text { APACHE II score within } \\
\text { 24 hours of admission }\end{array}$ \\
\hline Observation group $(\mathrm{n}=60)$ & $40.24 \pm 12.10$ & $63.22 \pm 12.54$ & $44 / 16$ & $14.30 \pm 6.20$ \\
Reference group $(\mathrm{n}=60)$ & $41.15 \pm 10.10$ & $63.75 \pm 13.50$ & $40 / 20$ & $14.80 \pm 6.40$ \\
$\mathrm{t}$ or $\chi^{2}$ value & 0.447 & 0.223 & 0.635 & 0.435 \\
$\mathrm{p}$ value & 0.656 & 0.824 & 0.426 & 0.665 \\
\hline
\end{tabular}

Note: comparison between observation group and reference group, $\mathrm{p}>0.05$

Comparison of observation indexes

Differences in the total duration of sedation, the prevalence of delirium, ICU length of stay, and mortality rate within 28 days between the observation and control groups were not statistically significant $(\mathrm{p}>0.05)$. However, the difference in time to spontaneous eye opening was statistically significant $(\mathrm{p}<0.05)$ (Table III).

Table III

Comparison of observation indexes between the observation and reference groups

\begin{tabular}{lcccc}
\hline \multicolumn{1}{c}{ Observation indexes } & $\begin{array}{c}\text { Observation group } \\
(\mathrm{n}=60)\end{array}$ & $\begin{array}{c}\text { Reference group } \\
(\mathrm{n}=60)\end{array}$ & $\mathrm{t}$ or $\chi^{2}$ value & $\mathrm{p}$ value \\
\hline Total duration of sedation $(\mathrm{h})$ & $34.74 \pm 17.77$ & $34.95 \pm 17.42$ & 0.065 & 0.948 \\
\hline Time to spontaneous eye opening (min) & $103.87 \pm 31.58$ & $15.33 \pm 4.56$ & 21.494 & 0.000 \\
\hline ICU length of stay $(\mathrm{d})$ & $5.73 \pm 2.79$ & $5.57 \pm 2.66$ & 0.323 & 0.748 \\
\hline The prevalence of delirium (incidence rate \%) & $10(16.7 \%)$ & $8(13.3 \%)$ & 0.261 & 0.609 \\
\hline Mortality rate within 28 days (mortality rate \%) & $3(5.00 \%)$ & $2(3.33 \%)$ & 0.208 & 0.648 \\
\hline
\end{tabular}

Case distribution in the total duration of sedation in the two groups

Comparing the observation group and the reference group, the differences in the cases in the three-time intervals of $0-24 \mathrm{~h}, 24-48 \mathrm{~h}$ and $48-72 \mathrm{~h}$ of total sedation duration between the two groups were not statistically significant $(\mathrm{p}>0.05$, Table IV).
Table IV

Total duration of sedation in the two groups

\begin{tabular}{lccc}
\hline \multicolumn{1}{c}{ Group } & \multicolumn{3}{c}{ Sedation duration $(\mathrm{h})$} \\
\cline { 2 - 4 } & $0-24$ & $24-48$ & $48-72$ \\
\hline Reference group $(\mathrm{n}=60)$ & 17 & 20 & 23 \\
\hline Observation group $(\mathrm{n}=60)$ & 16 & 21 & 23 \\
\hline Note: $\chi^{2}=0.055, \mathrm{p}=0.973$ & & &
\end{tabular}


The prevalence of adverse reactions during sedation in the two groups Differences in the prevalence of hypotension, bradycardia, nausea and other adverse reactions between the observation and reference groups were not statistically significant $(\mathrm{p}>0.05$, Table V).

Table V

Comparison of the incidence of adverse reactions in both groups

\begin{tabular}{lcccc}
\hline \multirow{2}{*}{ Group } & Normal & \multicolumn{3}{c}{ Adverse reactions } \\
\cline { 3 - 6 } & & Hypotension & Bradycardia & Nausea \\
\hline Reference group $(\mathrm{n}=60)$ & 52 & 3 & 1 & 4 \\
\hline Observation group $(\mathrm{n}=60)$ & 54 & 1 & 0 & 5 \\
\hline
\end{tabular}

Note: $\chi^{2}=0.323, p=0.570$

Differences in sedation effects between the two groups The difference in onset time of sedatives between the observation and reference groups was statistically

significant $(\mathrm{p}<0.05)$, the difference in the time to reach the optimal level of sedation was not statistically significant $(\mathrm{p}>0.05)$ (Table VI).

Table VI

Differences in sedation effects between the two groups

\begin{tabular}{lcccc}
\hline \multicolumn{1}{c}{ Group } & $\begin{array}{c}\text { Onset time of } \\
\text { sedatives }(\mathrm{s})\end{array}$ & $\begin{array}{c}\text { The time to reach the optimal } \\
\text { level of sedation }(\mathrm{min})\end{array}$ & $\begin{array}{c}\text { Wake up time } \\
(\mathrm{min})\end{array}$ & $\begin{array}{c}\text { Sedation depth } \\
(\text { SAS })\end{array}$ \\
\hline Reference group $(\mathrm{n}=60)$ & $27.90 \pm 7.60$ & $23.00 \pm 10.80$ & $15.33 \pm 4.56$ & Grade $3-4$ \\
\hline Observation group $(\mathrm{n}=60)$ & $60.80 \pm 10.30$ & $26.00 \pm 12.10$ & $103.87 \pm 31.58$ & Grade 3-4 \\
\hline $\mathrm{t}$ value & 19.909 & 1.433 & 21.494 & \\
\hline $\mathrm{p}$ value & 0.000 & 0.155 & 0.000 & \\
\hline
\end{tabular}

Various studies have revealed that $[5,6]$ the incidence of delirium in critically ill patients receiving mechanical ventilation in the ICU was high, reaching up to $80 \%$. Severe complications and unexpected events can occur in patients with delirium, causing relatively high disability rates and mortality, and bringing about heavy burden on society $[7,8]$. There are many causes of delirium in the clinic [9]. Drugs account for $15-75 \%$ of the causes of delirium. Furthermore, benzodiazepine sedatives are listed as high risk drugs for delirium [10]. At present, there are many studies on the pathogenesis of delirium $[11,12]$, but the exact mechanism remains unknown. The main hypotheses are as follows: [13, 15]: neurotransmitter imbalance theory, systemic inflammatory response theory, metabolic abnormality theory, macromolecular neutral amino acid theory, pharmacological mechanism theory, and stress response hypothesis. Benzodiazepine (midazolam or lorazepam) sedative drugs [16, 17] are presently known as important causes of delirium based on evidence. In particular, patients who received mechanical ventilation would have a very high incidence after being sedated for long periods of time. At present, radioligand binding experiments on the $\gamma$-aminobutyric acid (GABA) A receptor-benzodiazepine receptor-Cl-channel macromolecule complex revealed that $[18,19]$ the highaffinity binding site of midazolam in the brain is the benzodiazepine receptor. Its distribution is most concentrated in the cerebral cortex region, followed by the midbrain and limbic system, and the spinal cord and brain stem. The distribution of GABA neurotransmitter is basically consistent with the distribution of the central GABA A receptor. Electrophysiology has verified in an experiment that benzodiazepine drugs can enhance the neurotransmission function of central inhibitory neurotransmitter GABA and its synaptic inhibition, and enhance the function of GABA and its binding ability to its receptor. GABA A receptor gated channels are gated receptors in chloride channels. This receptor channel consists of $\alpha 2 \beta 2$, two $\alpha$ and $\beta$ subunits. The binding point of the $\beta$ subunit is the GABA receptor site. When GABA binds with it, $\mathrm{Cl}$-channels open and $\mathrm{Cl}$ influxes, causing hyperpolarization in nerve cells; and inhibition is induced. The benzodiazepine receptor is located on the $\alpha$ subunit. The combination of benzodiazepine drugs and the benzodiazepine receptor can increase the frequency of $\mathrm{Cl}$-channel opening, causing more $\mathrm{Cl}$ influx. Thus, drug efficacy would increase with the increase in dose, causing the effect to gradually increase from sedation and hypnosis to central muscle relaxation. At the time of withdrawal, synaptic inhibition and central inhibitory neurotransmitter GABA-ergic neurotransmission function decreases, GABA decreases, and the binding ability of central inhibitory transmitter GABA with its receptor decreases; which thereby result to the occurrence of rebound and withdrawal symptoms (insomnia, anxiety, excitement, tremors, etc.). This manifests as an acute confusion of consciousness-delirium.

The IPAD "guidelines" published in 2013 by the American Critical Care Medicine Association [20] pointed out that a sedation strategy of non-benzodiazepines (sedative drugs dexmedetomidine or propofol) is recommended for adult ICU patients with mechanical ventilation, since the improvement in clinical prognosis may be superior to that of 
benzodiazepines (midazolam or lorazepam), improving the clinical prognosis.

In the present clinical research, patients with mechanical ventilation who required sedation and analgesia in the ICU were included as subjects. With propofol (recommended by IPAD guidelines) as the sedative drug for the reference group and benzodiazepine drug midazolam as the sedative drugs for the observation group, a prospective randomized controlled clinical study was performed. The present study revealed that differences in the incidence of delirium, adverse reactions, ICU length of stay and 28-day mortality between the short duration of use of midazolam and propofol for patients who received mechanical ventilation were not statistically significant.

Furthermore, the time of onset of sedation and the time to spontaneous eye opening after sedation withdrawal were slightly longer. However, the difference in time to reach the optimal level of sedation between these two groups was not statistically significant, and the daily cost of the sedative was slightly lower.

The reason why the short duration use of midazolam does not increase the incidence of delirium may be because benzodiazepines have a higher binding rate with plasma proteins and higher fat-solubility, which rapidly distributes in tissues and accumulates in fat and muscle tissues, resulting in a very large volume of distribution. Its long-term use can cause the drug to accumulate in the body and induce an increase in the incidence of delirium; while its short-term use reduces the accumulation of drug and decreases the incidence of delirium induced by drug. Therefore, the long-term use of midazolam during mechanical ventilation can increase the incidence of delirium in patients, while the shortened duration of use of midazolam can reduce the incidence of delirium. A study revealed that [21] the long-term use of midazolam resulted in a greater decline in GABA level; and after withdrawal, severe rebound and severe withdrawal symptoms may occur, which induce delirium. Another studies revealed that $[22,23]$ proper sedation can reduce the incidence of delirium.

\section{Conclusions}

In summary, the present study revealed that the duration of use of benzodiazepine sedative drugs (midazolam) affects the incidence of delirium, and the short-term use of midazolam for sedation minimizes the incidence of delirium. Midazolam has the advantages of good sedation effect, economical and minimal effect on circulation. In particular, when it is used in ICUs in economically underdeveloped primary hospitals, the incidence of delirium is minimized and the patient's economic burden is reduced. The correct control of the duration of use can reduce the incidence of delirium. Patients with mechanical ventilation may still be given continuous sedation with midazolam for a short period of time.

\section{Conflicts of interests}

The authors declare no conflict of interest.

\section{References}

1. Zhao LB, Huang $X$, Advances in diagnosis and treatment of ICU delirium. J China Tradit Chin Med Inform., 2012; 4(1): 50-51.

2. McCusker J, Cole MG, Dendukuri N, Belzile E, Does delirium increase hospital stay?. J Am Geriat Soc., 2003; 51(11): 1539-1546.

3. van den Boogaard M, Pickkers P, Slooter AJ, Kuiper MA, Spronk PE, van der Voort PH, van der Hoeven JG, Donders R, van Achterberg T, Schoonhoven L, Development and validation of PRE-DELIRIC (PREdiction of DELIRium in ICu patients) delirium prediction model for intensive care patients: observational multicentre study. BMJ, 2012; 344: e420.

4. Pandharipande P, Cotton BA, Shintani A, Thompson J, Pun BT, Morris JAJr, Dittus R, Ely EW, Prevalence and risk factors for development of delirium in surgical and trauma intensive care unit patients. $J$ Trauma, 2008; 65(1): 34-41.

5. Álvarez EA, Garrido M A, Tobar EA, Prieto SA, Vergara SO, Briceño CD, González FJ, Occupational therapy for delirium management in elderly patients without mechanical ventilation in an intensive care unit: A pilot randomized clinical trial. J Crit Care, 2017; 37: 85-90.

6. Bulic D, Bennett M, Rodgers H, Nourse M, Rubie P, Looi JC, Van Haren F. Delirium after mechanical ventilation in intensive care units: The cognitive and psychosocial assessment (CAPA) study protocol. JMIR Res Protoc., 2017; 6(2): e31.

7. Skrobik Y, Delirium prevention and treatment. Anesthesiol Clin., 2011; 29(4): 721-727.

8. Inouye SK, Schlesinger MJ, Lydon TJ, Delirium: a symptom of how hospital care is failing older persons and a window to improve quality of hospital care. Am J Med., 1999; 106(9): 565-573.

9. Inouye SK, Delirium in older persons. N Engl J Med., 2006; 354(11): 1157-1165.

10. Lyons DL, Grimley SM, Sydnor, Double trouble: when delirium complicates dementia. Nursing, 2008; 38(9): 48-54.

11. Ouimet S, Kavanagh BP, Gottfried SB, Skrobik Y, Incidence, risk factors and consequences of ICU delirium. Intens Care Med., 2007; 33(1): 66-73.

12. Fitzgerald JM, The role of predictive coding in the pathogenesis of delirium. Med Hypotheses, 2017; 103: 71-77.

13. Maldonado JR, Pathoetiological model of delirium: a comprehensive understanding of the neurobiology of delirium and an evidence-based approach to prevention and treatment. Crit Care Clin., 2008; 24(4): 789-856.

14. Pustavoitau A, Stevens RD, Mechanisms of neurologic failure in critical illness. Crit Care Clin., 2008; 24(1): 1-24. 
15. Gunther ML, Morandi A, Ely EW, Pathophysiology of delirium in the intensive care unit. Crit Care Clin, 2008; 24(1): 45-65.

16. Liu LY, Chen CK, Mao WC, Tzeng NS, Delirium due to sepsis-associated encephalopathy mimicking alcohol withdrawal delirium. J Med Sci., 2017; 37(1): 23-25.

17. Hosker C, Ward D. Hypoactive delirium. BMJ, 2017; 357: j2047.

18. Maldifassi MC, Sigel E, Functional sites for anesthetics in GABAA receptors. Oncotarget, 2017; 8(7): 10779-10780.

19. Chua H C, Chebib M, GABA A receptors and the diversity in their structure and pharmacology. $A d v$ Pharmacol., 2017; 79: 1-34.
20. Yang L, Zhang M, 2013 ICU adult patient pain, restlessness and delirium treatment guidelines. Chin J Emerg Med., 2013; 22(12): 1325-1326.

21. Figueroaramos MI, Arroyonovoa CM, Lee KA, Padilla G, Puntillo KA, Sleep and delirium in ICU patients: a review of mechanisms and manifestations. Intens Care Med., 2009; 35(5): 781-795.

22. Ciuhu AN, Rahnea-Niță RA, Popescu M, Badiu CD, Pantea Stoian AM, Lupuliasa D, Gherghiceanu F, Diaconu CC, Rahnea-Niță G, Evidence of strong opioid therapy for palliation of breathlessness in cancer patients. Farmacia, 2017; 65(2): 173-178.

23. Hall JE, Uhrich TD, Barney JA, Arain SR, Ebert TJ, Sedative, amnestic, and analgesic properties of smalldose dexmedetomidine infusions. Anest Analg., 2000; 90(3): 699-705. 